\title{
Literature Review and a Conceptual Research Framework of Adaptive Street Lighting Criteria
}

\author{
Anwar Hassan Ibrahim \\ Department of Electrical Engineering \\ College of Engineering \\ Qassim University \\ Almulaidah Campus, Saudi Arabia \\ dr.anwar@qec.edu.sa \\ Meshal Ibrahim Almoshaogeh \\ Department of Civil Engineering \\ College of Engineering \\ Qassim University \\ Almulaidah Campus, Saudi Arabia \\ m.moshaogeh@qec.edu.sa
}

\author{
Fawaz Ali Alharbi \\ Department of Civil Engineering \\ College of Engineering \\ Qassim University \\ Almulaidah Campus, Saudi Arabia \\ f.a@qec.edu.sa
}

\author{
Abd Elaziz Mohamed Elmadina \\ Department of Optometry \\ College of Applied Medical Science \\ Qassim University \\ Almulaidah Campus, Saudi Arabia \\ a.alkhalil@qu.edu.sa
}

\begin{abstract}
Street lighting (SL) aims to improve security for street users during the night by expanding perceivability level by guaranteeing a certain luminance level. This paper introduces a brief investigation of previous researches on SL criteria and applications. The main objectives were to assess and indicate further research required in SL criteria, and explore additional aspects to improve their efficiency, with the Buraidah, Qassim region in Kingdom of Saudi Arabia used as a case study. This paper proposes additional limitations, alternative criteria, and their associated benefits.
\end{abstract}

Keywords-street lighting (SL); street lighting criteria; lighting environment and standardization; Buraidah-Qassim region

\section{INTRODUCTION}

The primary purpose of street lighting (SL) is to protect people from road traffic accidents [1, 2]. Many efforts and technological developments attempted to attain this goal and curb the economic toll that traffic accidents cause on national resources, as the reduction of accident cost justifies every investment in the optimization of street lighting [3]. The drivers' ability to react in varying road conditions and traffic tends to deteriorate at night hours, as the adaptation in scotopic vision takes time, affecting contrast sensitivity and visual acuity [2]. Perceptive reaction and color perception influence safety in road traffic. Therefore, studying SL is extremely important, as studies pointed that a relatively, high percentage of serious traffic accidents occur in darkness.

The term life of an electric lamp has two meanings: the time after which the lamp ceases its operation and the time after which the light output is reduced and potentially is less costly to replace it [4]. A few light sources are utilized in electric road lights. The most used types since 1940s within the US are: radiant, fluorescent, low-pressure sodium, and highly concentrated release lamps [5]. The main disadvantages of utilizing Low-Pressure Sodium (LPS) lights incorporate color rendering. When the light is on, everything around it looks either orange-yellow, dark, or shades in between them. Moreover, as the light ages it employs more wattage, and this increment results in small or no lumen deterioration, meaning that the light yield remains decently consistent over its life [6]. The spectral emission is concentrated at $589-589.6 \mathrm{~nm}$, which is close to the peak of the photopic curve. They are average in foggy or misty conditions, and water droplets do not disperse their monochromatic yellow light [4].

Street lighting is an important issue, especially for big cities, in order to increase the safety of driving and security, improving the quality of life by giving people the opportunity to continue their activity at nighttime [7]. Choosing the appropriate road lighting could offer a cash reduction rate by $30 \%$ in urban areas [8], and social aid to the public by counting the ability of smooth traffic flows. While this feature is usually accessible in evolved countries, many deficiencies exist in numerous territories in developing countries. The shortage of decent light quality at night can cause quality of life related problems [9]. Street lighting is additionally an intriguing security point, as it is one of the most popular themes among individuals and a basic action of local authorities. The quantity of lights and power prerequisites remain generally consistent over the daily working period [10]. The main variable is the amount of operation hours at night, as dictated by light perception, visual adaptation, varying climate, pavement type, etc.[11].

\section{BACKGROUND}

SL helps creating a safe environment for residents and business owners to live, work, play, and travel [12]. However, 
this essential need consumes a significant amount of energy, and is often tethered to substantial operation costs. Outdoor lighting can represent more than half of the municipal energy budget, depending on the size of the municipality, the scope of the offered services, and the efficiency of the public lighting. States and counties are also responsible for roadway lighting, including freeway, interstate, bridge, and tunnel lighting [13].

Roadway lighting reduced fatal accidents and injuries by $60 \%$ and property damage by $15 \%$ in [14]. However, as the electricity consumption of street lighting is considered high for the municipal authorities representing $10-40 \%$ of total consumption, many cities adopt new technologies in lighting systems [14]. In the last five years, a number of municipalities switched to new lighting technologies (e.g. induction and LED), in order to reduce energy costs by approximately $50 \%$ over conventional technologies, getting additional savings through lower operation and maintenance costs. While several options could be considered for adapting outdoor lighting to more efficient technologies, this paper largely refers to LED conversion, as it represents the majority of full-scale conversions by local governments and states $[15,16]$.

\section{ADAPTIVE LIGHTING INNOVATION DESIGN}

\section{A. Color Properties}

Color properties are related to the spectral composition of the emission, including color rendering and appearance. Color rendering portrays the appearance of the color beneath a given light compared with the appearance beneath a reference source. However, the color appearance of a light does not guide its color properties, as it is possible for the lights from two sources to be apparently identical in appearance, but have different color rendering properties. CIE has developed a method for indicating the color rendering properties of a light source. The color rendering index ranges from 0 to 100 , where 100 represents no color distribution [4]. Color appearance is the color of the light source or the color appearance of a white surface seen by its light, described in general as warm, intermediate or cold. [17] Cold colors have a bluish tinge, while warm colors are close to the red end of the visible spectrum. Filament lamps have warm colors, while highpressure mercury lamps have a cool appearance. The color appearance of a light source is classified according to CCT. The color temperature of a radiator is the absolute temperature $(\mathrm{K})$ of an ideal black-body radiator producing radiation of the similar chromaticity.

\section{B. Lamp Lifetime}

As mentioned above, the lifetime of an electric lamp has two meanings: the time after which the lamp ceases to operate, e.g. filament lamps failing due to filament breakage, or the time after which the light output is reduced so that it is more costeffective to replace the lamp [4].

\section{Luminaires}

Luminaires are designed to perform a number of functions. They provide electric connection, adapting and isolating the lamp from the environment, even if it is wet, corrosive, or hazardous, and most importantly they provide physical appearance and a light distribution pattern suitable for the application. Due to the variety of needs for lighting equipment, many different luminaire types exist on the market [18]. Planning for luminaires requires considering many perspectives such as aesthetics, ergonomics, and useful aspects in order to attain high efficiency. The American national standard practice for roadway lighting, sponsored and published by the Illumination Engineering Society of North America (IES) [4], defines the criteria for the classification of roadway, area, and high-mast luminaires. All classifications used in photometric data are based on lighting a strip running perpendicular to the cross arm of the luminaire, as a roadway would.

\section{RESEARCH GAP}

Modern demands and innovative technologies on street lighting constitute one of the hottest current research topics, but lighting criteria and standardization factors need to address all urban and suburban areas. So, there is a difficulty on the pertinence of alleged hypotheses, research, and their application on most common areas with the same lighting criteria. Thus, most researchers tried to advance the current comprehension in the area of lighting standards and application, by either hypothesis testing or a hypothesis augmentation approach. This paper investigates crucial lacking points and issues in street lighting, studying the Buriadah region, in Qassim, Saudi Arabia.

\section{STUDY AREA AND POPULATION}

The study area was Buraidah, Qassim in Saudi Arabia, an area which, among Qassim regions, is most affected by accidents. The study examined the existing lighting technology for deficiencies in order to propose ways to improve security and quality of light. The research targeted residents of the area aged from 20 to 70 . The sample size was determined by using the data obtained from the traffic police surveillance manual, in order to estimate the frequency of accidents at night due to street lighting deficiencies and their risk factors.

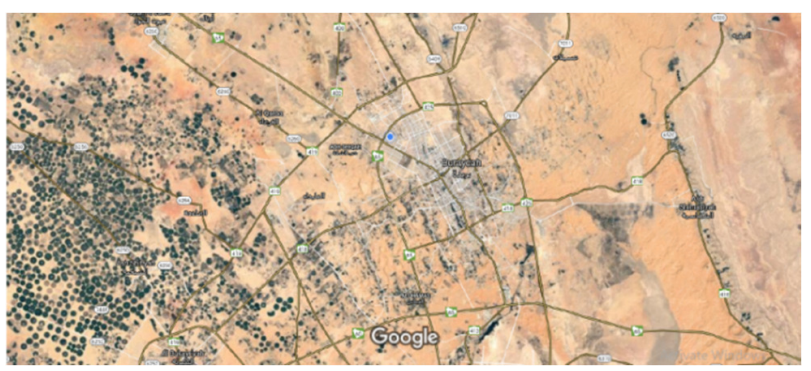

Fig. 1. Satellite map of Buraidah, (C) Google, TerraMetrics.

\section{RESEARCH FRAMEWORK}

Many studies have considered lighting criteria and the standardization process, providing adequate indications on effective cost and environmental factors, whereas the energy monitoring system could be utilized easily [29, 30]. An improvement of multi-attribute techniques of street lighting technologies was elaborated to develop a conceptual framework for understanding the technologies and the importance of lighting criteria. Figure 2 signifies the conceptual research hypotheses testing. 
TABLE I. BACK GROUND SUMMARY

\begin{tabular}{|c|c|c|c|c|c|}
\hline Ref. & What & How & Results and conclusion & Lacking points & Area for improvement \\
\hline [19] & $\begin{array}{c}\text { Decision support system for } \\
\text { assessing street lighting } \\
\text { based on environmental } \\
\text { criteria. }\end{array}$ & $\begin{array}{l}\text { Based on energy saving and } \\
\text { environmental benefits for } \\
\text { LED light sources indicators. }\end{array}$ & $\begin{array}{c}\text { Expanded energy investment funds } \\
\text { may be accomplished with natural } \\
\text { benefits. }\end{array}$ & $\begin{array}{c}\text { Expanded energy } \\
\text { investment funds may be } \\
\text { accomplished besides } \\
\text { natural benefits. }\end{array}$ & $\begin{array}{l}\text { Light visibility, roadway } \\
\text { lighting, pedestrian } \\
\text { discomfort, and glare at } \\
\text { urban LED lighting } \\
\text { must be considered. }\end{array}$ \\
\hline$[20]$ & $\begin{array}{l}\text { A pilot study of road and } \\
\text { cycle lighting, and obstacle } \\
\text { detection. }\end{array}$ & $\begin{array}{l}\text { Data measurement based on } \\
\text { rising detected obstacles. }\end{array}$ & $\begin{array}{l}\text { The diminishment in location was } \\
\text { balanced when diminishing street } \\
\text { lighting from } 2.0 \text { to } 0.2 \text { lux. }\end{array}$ & $\begin{array}{l}\text { Decreasing road lighting } \\
\text { is not a permanent } \\
\text { solution. }\end{array}$ & $\begin{array}{l}\text { Changing the angle of } \\
\text { the light following the } \\
\text { standard criteria. }\end{array}$ \\
\hline [21] & $\begin{array}{c}\text { LED road lighting in } \\
\text { practice: An evaluation of } \\
\text { compliance with regulations } \\
\text { and improvements for } \\
\text { further energy savings. } \\
\end{array}$ & $\begin{array}{l}\text { Energy saving investments } \\
\text { were considered. }\end{array}$ & $\begin{array}{l}\text { Street lighting for vehicular activity } \\
\text { satisfied most necessities, while for } \\
\text { pedestrians and bikes it did not } \\
\text { meet the constitutional necessities } \\
\text { for Uo and UI. } \\
\end{array}$ & $\begin{array}{l}\text { The measurement should } \\
\text { also target older people. }\end{array}$ & $\begin{array}{l}\text { Further energy saving } \\
\text { may miss the target of } \\
\text { international } \\
\text { standardization. }\end{array}$ \\
\hline$[22]$ & $\begin{array}{l}\text { Assesment of pedestrian } \\
\text { discomfort glare from urban } \\
\text { LED lighting }\end{array}$ & $\begin{array}{l}\text { Investigations were } \\
\text { conducted on a test track. }\end{array}$ & $\begin{array}{c}\text { Findings supported past work } \\
\text { which prescribed optics to } \\
\text { constrain most extreme and vertical } \\
\text { luminance. }\end{array}$ & $\begin{array}{l}\text { A comparative study of } \\
\text { the existing systems. }\end{array}$ & $\begin{array}{l}\text { Investigation of glare } \\
\text { rating during a walk. }\end{array}$ \\
\hline$[23]$ & $\begin{array}{c}\text { Comparative study of road } \\
\text { lighting efficiency in the } \\
\text { context of CEN/TR } 13201 \\
2004 \text { and } 2014 \text { standards and } \\
\text { dynamic control. } \\
\end{array}$ & $\begin{array}{c}\text { Energy utilization. One year } \\
\text { of activity concetrated } \\
\text { information were utilized. }\end{array}$ & $\begin{array}{l}\text { Results confirm the reduced cost } \\
\text { due to the impact of dynamic } \\
\text { control. }\end{array}$ & $\begin{array}{l}\text { The consideration brought } \\
\text { the essentially augmented } \\
\text { energy utilization due to } \\
\text { extra lighting necessities. }\end{array}$ & $\begin{array}{l}\text { Repeat measurements } \\
\text { on additional lighting } \\
\text { requirements. }\end{array}$ \\
\hline [24] & $\begin{array}{l}\text { Comments on empirical } \\
\text { evidence for the design of } \\
\text { public lighting. }\end{array}$ & $\begin{array}{l}\text { Light security was measured } \\
\text { through an on-street query of } \\
\text { pedestrians. }\end{array}$ & $\begin{array}{l}\text { An elective strategy such as day- } \\
\text { dark appraisals may be more } \\
\text { informative. }\end{array}$ & $\begin{array}{c}\text { Light range does not } \\
\text { influence face-based } \\
\text { interpersonal evaluations. }\end{array}$ & $\begin{array}{l}\text { Actual measurements } \\
\text { should be compined } \\
\text { with the questionnaire. }\end{array}$ \\
\hline$[25]$ & $\begin{array}{l}\text { Literature study about visual } \\
\text { clarity and spatial } \\
\text { brightness. }\end{array}$ & $\begin{array}{l}\text { Spatial brightness and visual } \\
\text { clarity. }\end{array}$ & $\begin{array}{l}\text { Differentiated definitions for spatial } \\
\text { brightness and clarity. }\end{array}$ & $\begin{array}{l}\text { The category rating } \\
\text { procedure depends on the } \\
\text { area of deployment. }\end{array}$ & $\begin{array}{l}\text { Experimenters ought to } \\
\text { take advanced exertion } \\
\text { to characterize the } \\
\text { nature of users' rating } \\
\text { items. }\end{array}$ \\
\hline$[26]$ & $\begin{array}{l}\text { Design of LED street } \\
\text { lighting adapted for free- } \\
\text { form roads. }\end{array}$ & $\begin{array}{l}\text { LED lamps that deliver a } \\
\text { roadway-shape light pattern. }\end{array}$ & $\begin{array}{l}\text { Simulation and measurement } \\
\text { results show the focal points of } \\
\text { versatile luminaires over } \\
\text { conventional approaches. }\end{array}$ & $\begin{array}{l}\text { LED street lights installed } \\
\text { in urban areas are } \\
\text { sacrificing illumination to } \\
\text { achieve energy saving. }\end{array}$ & $\begin{array}{l}\text { Required several optical } \\
\text { components that are } \\
\text { prone to alignment } \\
\text { issues while used in } \\
\text { roads with curves. }\end{array}$ \\
\hline$[27]$ & $\begin{array}{l}\text { Drivers' assesments on the } \\
\text { risks of distraction, poor } \\
\text { visibility at night, and } \\
\text { safety-related behaviors. }\end{array}$ & $\begin{array}{l}\text { Drivers surveyed on their } \\
\text { undestanding of dangers } \\
\text { related to driver diversion, } \\
\text { low perceivability at night, } \\
\text { and common safety-related } \\
\text { behaviors. }\end{array}$ & $\begin{array}{l}\text { Most drivers were completely } \\
\text { mindful of dangers related with } \\
\text { diversions from smartphones, in } \\
\text { spite of the fact that more young } \\
\text { drivers concede utilizing them. }\end{array}$ & $\begin{array}{l}\text { Different people have } \\
\text { different speed limits for } \\
\text { driving at day and night. }\end{array}$ & $\begin{array}{l}\text { It is recommended to } \\
\text { choose a group of } \\
\text { people with the same or } \\
\text { similar ages. }\end{array}$ \\
\hline$[28]$ & $\begin{array}{c}\text { Model calibration } \\
\text { methodology to assess the } \\
\text { actual lighting conditions of } \\
\text { a road infrastructure. }\end{array}$ & $\begin{array}{c}\text { Modeling recreation and } \\
\text { calibration of lighting scenes } \\
\text { for road lamps with GenOpt } \\
\text { software. }\end{array}$ & $\begin{array}{c}\text { Error as low as } 13 \% \text { for the } \\
\text { calculation of illuminance shows its } \\
\text { potential to survey the genuine } \\
\text { lighting conditions of a road. }\end{array}$ & $\begin{array}{l}\text { Software can only give a } \\
\text { visualization concept } \\
\text { rather than actual } \\
\text { perception. }\end{array}$ & $\begin{array}{l}\text { Light visibility and } \\
\text { roadway lighting criteria } \\
\text { need actual field study. }\end{array}$ \\
\hline
\end{tabular}

\section{DATA COLLECTION}

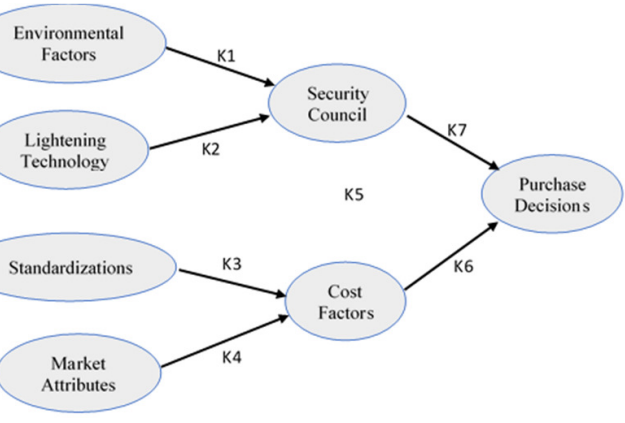

Fig. 2. Research hypotheses testing.

The lighting criteria in the study area typically affect the purchase decisions based on Security Council policy and cost factors. These factors are market attributes, lightening standardization, lightening technologies and environmental issues such as pavement, street width, pole height, etc.
The overall research aimed to study the performance and efficiency of the existing SL in Buraidah city, and calculate its impact on the drivers according to the international standards of lighting technology, the surrounding buildings, and the road designing strategies. The study was based on laboratory experiments to calculate the efficiency of lighting and its impact on the human eye. Moreover, a questionnaire was utilized to compare the perceptions of drivers when they drive on different of street lighting conditions. The targeted population was the people in Buraidah. Figure 3 describes the conceptual research plan and depicts the elaboration of two approaches to achieve the potential objectives and answer the research questions.

Most of the research in the area of SL has significant safety concerns. Clear street lighting offers a number of significant benefits, as it may improve safety for drivers and pedestrians, 
especially at urban areas. Streetlights installed at various locations throughout the city needed to be categorized. The initial research phase, presented in this paper, targeted the highest capacity intersections. Street and road lighting criteria were targeted considering that a satisfactory lighting structure is essential according to the standard criteria in Buraidah city.

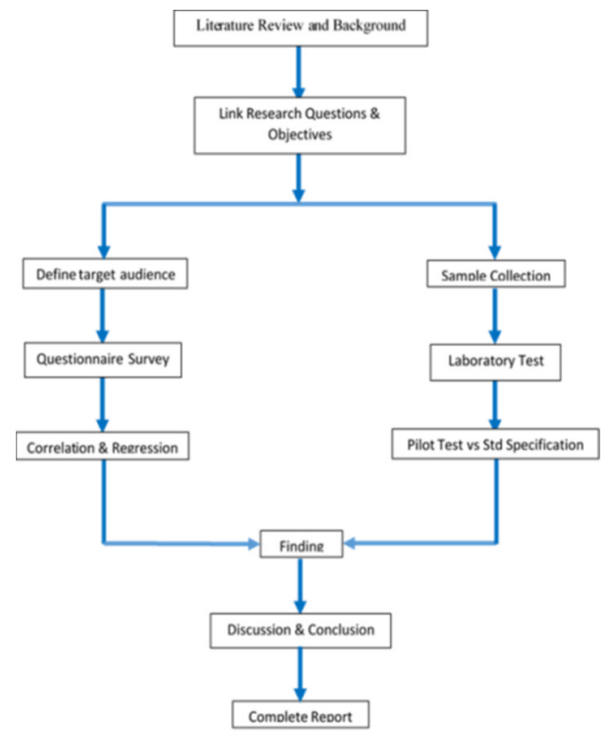

Fig. 3. Conceptual research plan.

\section{DISCUSSION}

Streetlight is a raised source of light on the edge of a street or road. Numerous lights have light-delicate photocells that actuate the light when required, for example at sunset or at the beginning of dull climate conditions. In most established lighting frameworks, a sunlight-based dial controls this feature. In this paper, municipal street lighting technologies were categorized according to power demand, lumens source (LPW) and life time per month as shown in Figure 4.

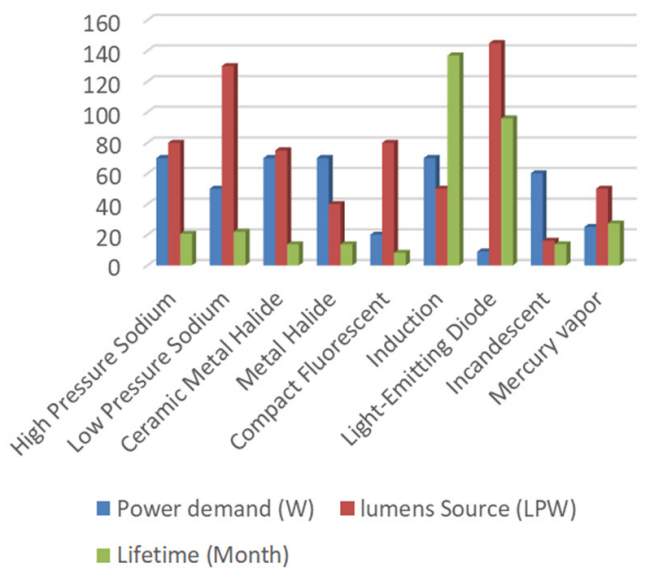

Fig. 4. Overview of street lighting source technologies.

\section{CONCLUSION}

Worldwide growth of lighting intensity with standard distribution comes with variations in the spectral density of lighting. As technology grows, LED high brightness streetlights replace old-fashioned ones such as high-pressure sodium (HPS) and low-pressure sodium (LPS). This paper presented various studies examining their street lighting criteria and applications. The study showed that the design and application of street lighting depends on environmental factors, market attributes, light technology, and standardization. Considering the specific qualities and significant measures for that application in the study area, will conform the importance of street light at Buraidah region.

\section{ACKNOLEDGEMENT}

The authors gratefully acknowledge Qassim University, represented by the Deanship of Scientific Research, on the financial support for this research under the number (5584-qec2O19-2-2-1) during the academic year 1440 AH /2019 AD.

\section{REFERENCES}

[1] P. Marchant, J. D. Hale, and J. P. Sadler, "Does changing to brighter road lighting improve road safety? Multilevel longitudinal analysis of road traffic collision frequency during the relighting of a UK city," Journal of Epidimiology \& Community Health, vol. 74, no. 5, pp. 467472, May 2020, doi: 10.1136/jech-2019-212208.

[2] C. Perkins et al., "What is the effect of reduced street lighting on crime and road traffic injuries at night? A mixed-methods study," Public Health Research, vol. 3, no. 11, Sep. 2015, doi: 10.3310/phr03110.

[3] P. Marchant, "Why Lighting Claims Might Well Be Wrong," International Journal of Sustainable Lighting, vol. 19, no. 1, pp. 69-74, Jun. 2017, doi: 10.26607/ijsl.v19i1.71.

[4] R. V. North, Work and the Eye, $2^{\text {nd }}$ ed. Oxford, UK: ButterworthHeinemann, 2001.

[5] "NEWMOA - Mercury Use in Lighting." http://www.newmoa.org/ prevention/mercury/imerc/FactSheets/lighting.cfm (accessed Jul. 02, 2020).

[6] S. L. Staff, "Lighting Comparison: LED vs High Pressure Sodium (HPS) and Low Pressure Sodium (LPS)." https://www.stouchlighting.com/ blog/led-vs-hps-lps-high-and-low-pressure-sodium (accessed Jul. 02, 2020).

[7] J. Corburn, "Confronting the Challenges in Reconnecting Urban Planning and Public Health," American Journal of Public Health, vol. 94, no. 4, pp. 541-546, Apr. 2004, doi: 10.2105/AJPH.94.4.541.

[8] M. Jackett and W. Frith, "Quantifying the impact of road lighting on road safety - A New Zealand Study," IATSS Research, vol. 36, no. 2, pp. 139-145, Mar. 2013, doi: 10.1016/j.iatssr.2012.09.001.

[9] Y. Hur and H. Adler, "Employees' Perceptions of Restaurant Brand Image," Journal of Foodservice Business Research, vol. 14, no. 4, pp. 334-359, Oct. 2011, doi: 10.1080/15378020.2011.624053.

[10] Roadway Lighting Design Guide, $4^{\text {th }}$ ed. American Association of State Highway and Transportation Officials, Washingthon, DC, USA, 2005.

[11] S. N. Baskara, H. Yaacob, M. R. Hainin, and S. A. Hassan, "Accident due to pavement condition - A review," Jurnal Teknologi, vol. 78, no. 72, pp. 75-82, Mar 2016.

[12] M. S. Rea, J. D. Bullough, C. R. Fay, J. A. Brons, J. Van Derlofske, and E. T. Donnell, "Review of the Safety Benefits and Other Effects of Roadway Lighting,” Jun. 2009, Accessed: Jun. 23, 2020. [Online]. Available: https://trid.trb.org/view/1631596.

[13] "Outdoor Lighting Challenges and Solution Pathways | Better Buildings Initiative." https://betterbuildingssolutioncenter.energy.gov/ resources/outdoor-lighting-challenges-and-solution-pathways (accessed Jul. 02, 2020) 
[14] G. Al-Haji, "The Impact of New Street Lighting Technologies on Traffic Safety," Journal of Traffic and Logistics Engineering, vol. 2, no. 3, pp. 202-205, 2014, doi: 10.12720/jtle.2.3.202-205.

[15] R. Ciriminna, L. Albanese, F. Meneguzzo, and M. Pagliaro, "LED Street Lighting: A Looking Ahead Perspective," Green, vol. 5, no. 1-6, pp. 8394, Dec. 2015, doi: 10.1515/green-2015-0020.

[16] S. M. Witt, S. Stults, E. Rieves, K. Emerson, and D. L. Mendoza, "Findings from a Pilot Light-Emitting Diode (LED) Bulb Exchange Program at a Neighborhood Scale," Sustainability, vol. 11, no. 14, Jan. 2019, doi: 10.3390/su1 1143965, Art no. 3965.

[17] D. W. Durrant, Interior Lighting Design, 5th ed. London, UK: Lighting Industry Federation Limited and the Electricity Council, 1977.

[18] C. R. B. S. Rodrigues, P. S. Almeida, G. M. Soares, J. M. Jorge, D. P. Pinto, and H. A. C. Braga, "An experimental comparison between different technologies arising for public lighting: LED luminaires replacing high pressure sodium lamps," in 2011 IEEE International Symposium on Industrial Electronics, Jun. 2011, pp. 141-146, doi: 10.1109/ISIE.2011.5984147.

[19] L. T. Doulos, I. Sioutis, P. Kontaxis, G. Zissis, and K. Faidas, “A decision support system for assessment of street lighting tenders based on energy performance indicators and environmental criteria: Overview, methodology and case study," Sustainable Cities and Society, vol. 51, Nov. 2019, doi: 10.1016/j.scs.2019.101759, Art no.101759.

[20] S. Fotios, H. Qasem, C. Cheal, and J. Uttley, "A pilot study of road lighting, cycle lighting and obstacle detection," Lighting Research \& Technology, vol. 49, no. 5, pp. 586-602, Aug. 2017, doi: $10.1177 / 1477153515625103$.

[21] A. K. Jägerbrand, "LED (Light-Emitting Diode) Road Lighting in Practice: An Evaluation of Compliance with Regulations and Improvements for Further Energy Savings," Energies, vol. 9, no. 5, May 2016, Art. no. 357, doi: 10.3390/en9050357,.

[22] C. Villa, R. Bremond, and E. Saint-Jacques, "Assessment of pedestrian discomfort glare from urban LED lighting," Lighting Research \& Technology, vol. 49, no. 2, pp. 147-172, Apr. 2017, doi: $10.1177 / 1477153516673402$

[23] I. Wojnicki, K. Komnata, and L. Kotulski, "Comparative Study of Road Lighting Efficiency in the Context of CEN/TR 132012004 and 2014 Lighting Standards and Dynamic Control," Energies, vol. 12, no. 8, Jan. 2019, Art. no. 1524, doi: 10.3390/en12081524.

[24] S. Fotios, "Comment on empirical evidence for the design of public lighting," Safety Science, vol. 86, pp. 88-91, Jul. 2016, doi: 10.1016/j.ssci.2016.02.020.

[25] S. Fotios and D. Atli, "Comparing Judgments of Visual Clarity and Spatial Brightness through an Analysis of Studies Using the Category Rating Procedure," $L E U K O S$, vol. 8, no. 4, pp. 261-281, Apr. 2012, doi: 10.1582/LEUKOS.2012.08.04.002.

[26] C. C. Sun et al., "Design of LED Street Lighting Adapted for Free-Form Roads," IEEE Photonics Journal, vol. 9, no. 1, pp. 1-13, Feb. 2017, doi: 10.1109/JPHOT.2017.2657742.

[27] P. Mikoski, G. Zlupko, and D. A. Owens, "Drivers' assessments of the risks of distraction, poor visibility at night, and safety-related behaviors of themselves and other drivers," Transportation Research Part F: Traffic Psychology and Behaviour, vol. 62, pp. 416-434, Apr. 2019, doi: 10.1016/j.trf.2019.01.011.

[28] A. Ogando-Martínez, F. Troncoso-Pastoriza, P. Eguía-Oller, E. GranadaÁlvarez, and A. Erkoreka, "Model Calibration Methodology to Assess the Actual Lighting Conditions of a Road Infrastructure," Infrastructures, vol. 5, no. 1, Jan. 2020, doi: 10.3390/infrastructures5010002, Art no. 2.

[29] R. Govindarajan, S. Meikandasivam, and D. Vijayakumar, "Performance Analysis of Smart Energy Monitoring Systems in Real-time," Engineering, Technology \& Applied Science Research, vol. 10, no. 3, pp. 5808-5813, Jun. 2020

[30] R. Pereira, J. Figueiredo, R. Melicio, V. M. F. Mendes, J. Martins, and J. C. Quadrado, "Consumer energy management system with integration of smart meters," Energy Reports, vol. 1, pp. 22-29, Nov. 2015, doi: 10.1016/j.egyr.2014.10.001. 